\title{
Small business economics journal editor of the year award
}

\author{
Zoltan Acs for the Editors of Small Business Economics Journal
}

Accepted: 12 April 2021 / Published online: 17 May 2021

(C) The Author(s), under exclusive licence to Springer Science+Business Media, LLC, part of Springer Nature 2021

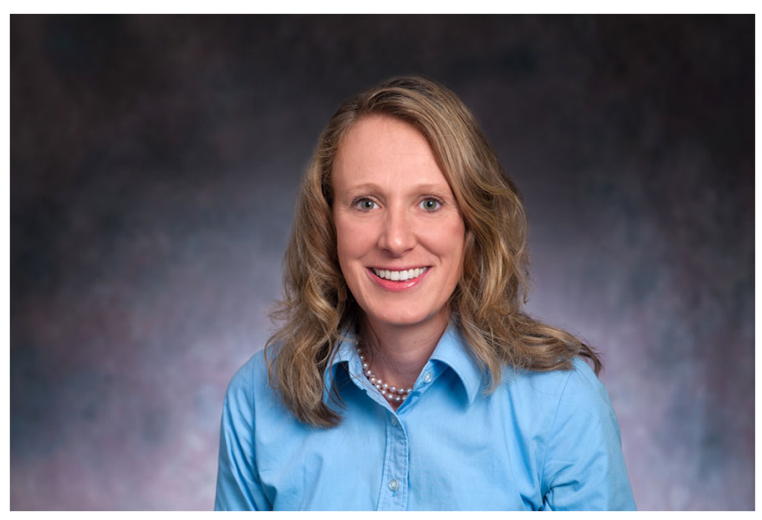

Dr. Siri Terjesen of Florida Atlantic University and the Norwegian School of Economics is the winner of the 2021 Small Business Economics journal editor of the year award.

Siri Terjesen is Associate Dean, Research \& External Relations and Phil Smith Professor of Entrepreneurship at Florida Atlantic University (FAU) in Boca Raton, Florida, and Professor .2 at the Norwegian School of Economics (Norges Handelshøyskole: NHH) in Bergen, Norway. She joined FAU in August 2019 from American University in Washington, D.C., where she served as Professor and Director of the American University Center for Innovation and was co-PI of the NSF I-Corps site grant to commercialize tech-based entrepreneurship.

\section{Z. Acs $(\bowtie)$}

George Mason University, Arlington, VA 22201, USA

e-mail: zacs@gmu.edu
Siri's research focuses on entrepreneurship, corporate governance, and strategy and is published over 80 articles, two books, and a variety of white papers for, among others, the Kauffman Foundation, the World Bank, and the U.S. Small Business Administration. She is nominated to serve as a director on the U.S. National Board for Education Science, which advises the U.S. Department of Education's Institute for Education Sciences. Previously Dr. Terjesen has served as a reviewer for similar nationallevel efforts for the Swedish and Norwegian governments' higher education system. She is an affiliated researcher with Catalyst (New York), Indiana University's Institute for Development Strategies, and the Ratio Institute (Stockholm), and serves on the board of Strata, a 501c3 attached to Utah State University.

As a regular contributor to the field of entrepreneurship, Dr. Terjesen has performed service to Small Business Economics Journal over the years as a reviewer and an associate editor.

Our heartfelt congratulations and thanks to Dr. Terjesen for her years of service to the journal.

Since 2016: Editor of Small Business Economics

Since 2014: Associate Editor of Small Business Economics

Publisher's note Springer Nature remains neutral with regard to jurisdictional claims in published maps and institutional affiliations. 